\title{
The Encroaching Graduate Schools
}

\author{
Mr. Hare is librarian of the University \\ of Denver.
}

$\mathrm{I}^{\mathrm{P}}$ WE agree that a university library capable of supporting research is one having the major part of the literature in those fields of graduate study offered by the institution, as well as a teaching, research and library staff capable of servicing it, then we may conclude that there are not more than a score of universities in the United States having adequate library resources to do graduate work in any considerable variety of departments.

It follows logically that any institution which cannot afford such library resources is misspending any funds used to maintain its graduate school. This is true particularly of any money invested in library research materials, namely, such materials as will be used almost exclusively by graduate students and faculty, and little, or not at all, by undergraduates. Indeed, it will be the contention of this paper that such expenditures constitute an encroachment upon the needs of the undergraduate body, to whose instruction all American institutions, except the few referred to above, should be restricted.

Furthermore, American librarians are partly to blame that this situation exists; first, because some have not had the courage to assert the weaknesses of their collections, and the sheer impossibility of giving adequate support to graduate study, and second, because those who have called attention to the ridiculousness of such pro- grams of instruction have allowed themselves to be ignored by the other university authorities.

\section{Librarian in an Advantageous Position}

In any case, now when America is so seriously pondering the continuance of its several hundreds of colleges and universities, there is an opportunity for librarians to be of assistance in these deliberations, because the librarian is in the advantageous position of one who can advise his colleagues about the availability of resources which, of all things except money, should govern the policy of the institution.

The commonness of the supposition that a college or university must grant advanced degrees is attested by the fact that there is hardly suclr a school in this country which does not award at least the master's degree. And yet the graduate students in the great majority of these institutions constitute a minor percentage of the total enrolment. And it is enrolment (tuition) which supports most of the endowed schools. Fifty to 90 per cent of the operating costs of these colleges and universities are paid by tuition, with the high percentages prevailing, whereas 40 per cent is generally considered a maximum consistent with high academic standards. The state-supported schools are hardly less mercenary, in the absence of adequate constitutional guarantees.

There is no valid reason for having a graduate school in many institutions. Alumni pride in the alma mater, like the 
equally intangible and unreliable pride in its football team, is partly accountable. But the more culpable are the faculty and administrative officers, who apparently cannot believe that their school is the equal of its neighbor if it does not excel in enterprises: variety of courses in the undergraduate school, in order to compete for matriculations; and variety and superlativeness of advanced degrees awarded, apparently for the sheer impressiveness of their announcement in the baccalaureate ceremonies and catalogs.

\section{Little Account Taken of \\ Library's Resources}

Willingness of a jealous, or docile, faculty, therefore, seems too frequently to have been the only criterion for decisions to give graduate instruction. No account, or too little, has been taken of the library's resources. And this, as said above, is largely the librarian's fault. He should have asked for a showdown in the faculty meeting when the issue was decided. True, he may not have been allowed there. His opinion may not have been considered important. Too often this is a correct appraisal. Certainly the absence of courage, either in faculty discussion, if the librarian is present, or later if he is not, has frequently resulted in poorly advised decisions to undertake advanced instruction.

But the point now is that the librarian must reveal to his colleagues the limits of the resources of the library. He should insist that, if a full program of graduate study is to be undertaken, he must have hundreds of thousands, not tens of thousands, of dollars to spend annually. That amount is spent on the libraries of the great graduate schools mentioned abovethe score which have adequate library re- sources. See, for example, the multigraphed list of library budgets issued annually by the Princeton University $\mathrm{Li}$ brary.

Or, he may find it possible to show that only a limited number of fields of graduate study may be undertaken, allowing the neighboring schools to handle certain fields in which they may have strong library resources. But he must insist that the fields chosen for graduate study in his institution be supported before giving his approval to their adoption. This support, again, means very large amounts of money for books and capable library personnel, quarters, equipment, supplies, maintenance. The librarian should insist upon what amounts to a contract that the funds to afford his specifications be guaranteed.

A definite agreement should be arrived at with the neighboring schools about cooperation in thus dividing the responsibilities for graduate work. Misunderstandings could be costly. It is not unusual for a great research library to spend a quarter of a million dollars in building up the collection in one field over a period of a dozen years. If two schools in the same region duplicated purchases, even though they spent less than that figure, the waste would be unpardonable.

It is not without some justification that this matter of cooperation and its weaknesses is mentioned, for thusfar only limited progress has been made.

The several state consolidations of their respective systems of higher education represent very important progress toward intelligent cooperation. But few of these state systems have yet accomplished impressive transfer of schools, departments and divisions to the proper institutions. Meanwhile, the privately endowed colleges and universities continue to compete 
with the state institutions, and with each other, by as extensive curricular duplication as possible. I refer here to graduate instruction in particular, enormously more expensive per student, or per any other unit, than undergraduate, which is duplicated in nearly all of these colleges and universities as a matter of course.

Correspondingly, it is evident that the great graduate schools cannot afford undergraduate schools. True, endowments do not support the graduate schools, and they must rely for sustainment upon the tuition paid by the undergraduates. But we are aware that this is hardly fair to the undergraduate. Obviously, the graduate school must be further endowed. How? Jointly by the states, by the federal government, and by philanthropy. Certainly it would be cheaper for many states to participate in a cooperative graduate school, perhaps by means of scholarships, than to support their own separate school, or schools, as is more often the case.

Thus, a considerable part of the money now spent on their own graduate schools would be freed for use in the undergraduate work, providing a higher quality of instruction there. Relieved of its graduate school demands (expensive source materials, as well as funded knowledge), the undergraduate library could maintain higher standards per dollar spent. A good undergraduate library is a comparatively small collection of useful books, easily and inexpensively administered and maintained. That is, a minimum of $\$ 25,000$ per year would sustain such a library. "Number of volumes" is no longer con- sidered indicative of anything except storage space. "Number of titles" is a valuable measure for a research library. But "number of useful titles" is the most reliable standard for an undergraduate library. The needs of teachers interested in research must be met by leaves of absence, and by interlibrary loans, photoduplication, and, of course, by occasional connived purchases.

The college and university librarian's opportunity to give valuable advice and to participate in decisions and actions which affect the course of American education is in direct proportion to the importance of books in the scheme of education. Because instruction is impossible without them, only such study as can be so supported should be undertaken.

May one not reasonably conclude, therefore, that with the exception of the few great universities in this country which have the money to undertake graduate work in numerous fields, and the few cases where colleges or universities can afford a limited number of fields of graduate study (say, conservatively, five to ten thousand dollars per year per field for the library alone, plus a really adequate basic collection of books and periodicals), with the exception of these, instruction in American colleges and universities should be limited to undergraduate studies. The undergraduate curriculums should be planned, insofar as these schools remain vocational, to distribute the emphasis among the schools best equipped to handle the work. And, specifically, it is the librarian's job to see that the consideration of equipment includes appraisal of library resources. 